\title{
EFFECTS OF COCO-PEAT, VERMICOMPOST AND PRO-MIX GROWTH MEDIA ON THE GROWTH AND DEVELOPMENT OF BOULANGER (SOLANUM MELONGENA) AND TOMATO (SOLANUM LYCOPERSICUM) SEEDLINGS: A COMPARATIVE STUDY
}

\author{
*Lalita Gopaul, Bibi Nariefa Abrahim, Oudho Homenauth
}

Hope Coconut Industries Limited, Guyana

*Corresponding Author

DOI: https://doi.org/10.51193/IJAER.2021.7409

\begin{abstract}
The use of suitable growth medium in nurseries is necessary for the production of seedlings of excellent qualities. In light of climate change and its effects, there is an urgent need for the replacement of synthetic growth media with organic alternatives. Currently the waste of Guyana's expanding coconut industry is posing a solid waste management issue; as such it can be converted and used as an organic growth medium in the form of cocopeat. This study sought to compare the effects of cocopeat, vermicompost, and promix growth medium on the growth and development of boulanger and tomato seedlings. Four treatments were evaluated using an experimental approach in a randomised complete block design. Data was obtained on the physical and chemical properties of the medium and the growth parameters of the seedlings. Results indicated that promix had the best bulk density and water holding capacity followed by cocopeat and then vermicompost. It was found that the mixture of vermicompost and cocopeat produced boulanger seedlings with the most leaves, widest leaves and highest fresh weight while vermicompost produced boulanger seedlings of the tallest shoots and longest leaves. On the other hand, the mixture of cocopeat and vermicompost produced tomato seedlings of the tallest shoots, longest leaves, and longest roots while vermicompost produced those with the most leaves and highest fresh weight. These were followed by the seedlings produced in cocopeat and then by those produced in promix for both boulanger and tomato. The results of this study concluded that the mixture of vermicompost and cocopeat at a 1:1 ratio is the ideal growth medium for boulanger and tomato seedling production as the vermicompost supplies the ready to use nutrients while cocopeat provides an ultimate environment for root development.
\end{abstract}

Keywords: Growth medium, Cocopeat, Vermicompost, Pro-mix, Tomato, Boulanger, Seedlings 


\section{LIST OF ABBREVIATIONS}

$\mathrm{cm}^{2}-\quad$ cubic centimeter

$\mathrm{Cu}-\quad$ copper

Fe- Iron

g- $\quad$ grams

K- potassium

Mg- magnesium

Mn- manganese

$\mathrm{N}-\quad$ nitrogen

P- phosphorous

TOC- total organic carbon

WHC- water holding capacity

wt.- weight

Zn- $\quad$ zinc

\section{INTRODUCTION}

\subsection{Background}

The green revolution was initiated in the 1960's to address malnutrition issues in the developing world and in many cases has achieved self-sufficiency in food production (Singh, 2000). It saw a rapid increase in production with the use of technology and synthetic fertilisers in the agriculture sector (Tilman, 1998). This period yielded great results in food production but gave rise to continuous negative impacts on the environment (soil, water and air) from the manufacture and over use of these synthetic products (Singh, 2000). As the uses of chemical inputs are escalating, organic matter levels are being depleted reducing fertility (Tilman, 1998). As this was realized over the years, there is now a pressing call for the switch from inorganic agricultural inputs to organic methods in a phenomenon called "greening the green revolution".

Simultaneously, the coconut industry in Guyana has received great attention in recent years and has seen massive developments. Increasing production within the coconut industry however, 
International Journal of Agriculture and Environmental Research

ISSN: 2455-6939

Volume: 07, Issue: 04 "July-August 2021"

comes with the challenge of waste disposal. The shell and husk in particular are posing solid waste issues because in most cases they are dumped or burned in the open, releasing carbon dioxide, methane and other greenhouse gases; the main drivers of climate change. To address both the issues of environmental pollution and consequently climate change from the use of inorganic agricultural products and poor solid waste management in the coconut industry, this research seeks to utilise the waste from the coconut industry as an organic growth medium.

\subsection{Research Aim}

The general aim of this study is to utilise the waste (coconut husk) of the coconut industry in the form of cocopeat as a growth medium for tomato and boulanger seedlings production. The specific objectives are:

1. To compare the physical and chemical properties of cocopeat, vermicompost and promix growth media

2. To assess the effects of coco-peat, vermicompost and pro-mix growth media on biomass, shoot and root development of boulanger and tomato seedlings

\subsection{Context and Rationale of Study}

Agriculture is known to be one of the major contributors to greenhouse gases emission. As Guyana is moving towards becoming a Green State, there is need for the use of environmentally friendly agricultural techniques. Over the years the coconut industry has been undergoing major developments. While the coconut water and meat are sold, packaged for export or used to produce value added products such as coconut biscuits, an issue arising is the unsustainable disposal of the coconut husk and shell. These in most cases are dumped or burned in the open producing carbon dioxide and other greenhouse gases. Since little is done to sustainably manage coconut waste, this study seeks to use this waste in the shredded form called cocopeat. This will reduce the dependence on commercial synthetic growth medium while contributing to environmental protection and possibly produce seedlings of better quality.

\subsection{Scope of Study}

This study took the form of an experiment and it sought to compare the effects of four growth medium on two seedling types; boulanger and tomato. Since this is a baseline study, the number of crops was not expanded. Growth parameters of the seedlings were measured at a transplantable age only and did not continue beyond. The growth parameters measured were shoot length, number of leaves, leaf length, leaf width, root length and fresh weight of seedling. Since tomato leaves are compound in nature, leaf width was not analysed. Additionally, this study was focused only on root, shoots growth and total biomass of the two seedling types and 
International Journal of Agriculture and Environmental Research

ISSN: 2455-6939

Volume: 07, Issue: 04 "July-August 2021"

does not include germination analyses. Physical and chemical analyses of the growth medium were done to support the growth parameters findings.

\section{LITERATURE REVIEW}

\subsection{Introduction}

In recent decades there has been increasing awareness of environmental issues and this has triggered the need to dispose of, reduce, reuse and recycle the rising amounts of waste. There is also the need to reduce the consumption of non-renewable resources such as inorganic agricultural inputs and promote the use of organic products in agriculture. Together with rising environmental concerns, the coconut industry in Guyana has been expanding rapidly, supplying both local and international markets with ripe nuts, dried nuts and also value added products (NAREI, 2017). The disposal of the waste from this industry is however posing a solid waste management issue and as such converting this waste to valuable product is necessary. Farmers in the Region Two Pomeroon area have already began shredding the coconut to produce cocopeat, a material with several beneficial uses, one being a growing medium for seedling production.

Seedling production is an important step in agricultural systems as it can influence the final crop yield. A growth medium is a substance through which seeds germinate and plant roots grow andextract water and nutrients (Wilkinson et al., 2014). There are two general types of growth media used in nurseries; inorganic based and organic based (Wilkinson et al., 2014). Using a suitable growing medium is important for crop production since they have proven to influence the quality of seedlings and consequently the productivity of the plant after transplanting (Bhardwaj, 2014). This is because plants depend on their media for physical support for growth, nutrients, water and for gaseous exchange between the roots, the surroundings and the medium (Abad et al., 2002). Currently, top soil and commercial potting mixtures are being used as a part of growing medium by many nurseries.

\subsection{Commercial Growth Media}

Presently, there are a variety of commercial growth media mixes available on the market. One such packaged medium on the market in Guyana is Promix. These mixes are usually made up of a combination of organic and inorganic ingredients. Wilkinson et al. (2014) identified vermiculite, perlite, pumice and polystyrene beads as common inorganic materials used with sand to form commercial growth media. Promix available on the market in Guyana contains sphagnum peat-moss, perlite, vermiculite, dolomitic and calcitic limestone, wetting agent and mycorrhizae. These materials have low bulk densities, neutral $\mathrm{pH}$, high water-holding capacity and when used in growing media, makes it well drained, well aerated and resistant to decomposition (Wilkinson et al., 2014; Mastalerz, 1977). Manufacturers of these products 
International Journal of Agriculture and Environmental Research

ISSN: 2455-6939

Volume: 07, Issue: 04 "July-August 2021"

usually sterilise and amend the mixtures with wetting agents, hydrophilic gels and fertilizers as a marketing strategy (Wilkinson et al., 2014 and Riaz et al., 2008).

Mathowa et al. (2016) evaluated commercial growth media (hydromix) on tomato (Lycopersicon esculentum L.) and found that there were no significant difference in emergence of seedlings grown in cocopeat and hydromix. The commercial media however produced taller seedlings with larger leaves than the cocopeat medium. In another study, tomato plants grown in promix were $32 \%$ shorter and possessed $12 \%$ less leaves than those grown in substrate mushroom compost (Eudoxie and Alexander, 2011). Since commercial potting media such as promix are non-renewable in nature and are usually not produced locally, alternative sustainable soiless media are being explored (Awang et al., 2009). Two main soiless potting media available in Guyana are cocopeat and vermicompost.

\subsection{Cocopeat}

Cocopeat is an agricultural by-product obtained from the extraction of fiber from coconut husk (Abad et al, 2002). It is an affordable growth medium for raising seedlings in nurseries, especially for vegetable crops in the tropics (Sriram et al., 2010). It is considered to be a suitable organic growth medium since it has an acceptable $\mathrm{pH}$ and electrical conductivity (Awang et al., 2009). Cocopeat is free of pathogens, has a high water-holding capacity, excellent drainage, excellent physical resiliency, slow decomposition and easy wettability; all properties that makes it a suitable growth medium (Wilkinson et al., 2014). On the other hand, Wilkinson et al., (2014) also found cocopeat to be low in nitrogen, calcium, and magnesium but relatively high in phosphorus and potassium. It has the ability to store and release nutrients slowly over a period of time, it can be mixed with other growers and it is also reusable in nurseries making it an ideal growth medium (Sriram et al., 2010).

The results of many studies found cocopeat to be a suitable growth medium for several crops. Bhardwaj (2014) found cocopeat to be successful when used as a potting soil for roses, vegetables and other crops. Sindhu et al, (2010) found that gerbera grown in soilless potting mixtures comprising of cocopeat showed better vegetative growth and also experienced early flowering. The flower quality of gerbera in cocopeat was also better than the other mixtures which contained vermicompost, smridhi additive and farm yard manure. When compared to different potting mixtures comprising of burnt rice husk, perlite and kenaf core fiber, cocopeat has shown similar effects on plant height, plant weight and flowering of Celosia cristata (Awang et al., 2009). Cocopeat has also improved the physical quality of potting mixtures. Kukal et al., (2010) found that cocopeat amended soil mixtures have higher water holding capacity than the other treatments. Khayyat et al., (2007) reported improved growth performances of Epipremnum 
International Journal of Agriculture and Environmental Research

ISSN: 2455-6939

Volume: 07, Issue: 04 "July-August 2021"

aureum grown in cocopeat (coir based). This was attributed to better aeration, drainage conditions and water maintenance capability of the substrate.

\subsection{Vermicompost}

Vermicompost, another growth medium, is formed from the mesophilic biotechnological process where earthworms breakdown organic matter such as cow manure in a controlled environment, reducing its volume by $40-60 \%$, producing an end product that is a peat-like material (Abrahim et al., 2016). The physical activity of the earthworms results in fragmentation of the material thereby increasing surface area and aeration (Yadav et al., 2013). They degrade the organic material biochemically through their enzymatic digestion while their excrement enriches the nutrient content of the soil (Yadav et al., 2013). Vermicomposts made from several animal dung, are rich in nitrogen, phosphorous and potassium while their carbon:nitrogen ratio are below 15 making them suitable soil conditioners (Yadav et al., 2013). Vermicompost could be an environmentally friendly replacement for peat in growth media since it has shown similar or beneficial effects on seedling performance and fruit quality (Zaller, 2007).

Abrahim et al., (2016) found that vermicompost produced Brassica rappa spp. Chinesis (pakchoi), Lactuca sativa (lettuce) and Brassica oleracea var. capitata (cabbage) with qualities (number of leaves and plant weight) comparable to those fertilized with synthetic fertilizers. When used for tomato seedling production, vermicompost amended medium significantly influenced theemergence and elongation of seedlings (Zaller, 2007). Biomass allocation (root:shoot ratio) was also better for two varieties of tomatoes amended with vermicompost in the seedling stage (Zaller, 2007). Similarly, tomato andlettuceseedlings produced using cow manure-based vermicompost showed enhanced growth (Atiyeh et al., 2000). Leaf area, plant shoot biomass and weight of peppers were all enhanced when vermicompost was used as growing medium (Arancon et al., 2005).

\subsection{Boulanger and Tomato}

This research entails the usage of cocopeat as growing medium for the production of boulanger and tomato seedlings. Boulanger (Solanum melongena) and tomato (Solanum lycopersicum) belong to the Solanaceae family and are produced year-round in Guyana. The Long Purple variety of Boulanger used in this experiment is deep purple in colour, long, smooth and segmented (Ministry of Agriculture 2007). The F1 Mongol variety of tomato was used in this experiment because it thrives efficiently under dry hot conditions that prevails in Guyana and it is also resistant to nematodes and bacterial and fungal diseases (Sereme et al., 2016). Boulanger and tomato are two of the main vegetable crops cultivated in Guyana and are used in a variety of local foods. While boulanger is consumed cooked, tomato is consumed raw, cooked or 
processed into juices and paste. They are marketed mostly locally with small fractions being exported (Ministry of Agriculture, 2007; NARI et al., 2003).

Boulanger and tomato are warm season, day-neutral plants that thrive well in Guyana's climatic conditions, in fertile medium loams and well-drained soils of $\mathrm{pH}$ around 5.5-6.8 (Ministry of Agriculture, 2007). They are grown widely on farms across all the regions of Guyana but mostly on larger scales in Regions Three, Four and Six (Ministry of Agriculture, 2007). Over the years boulanger production has been expanding while tomato processing has been rapidly escalating. Given this increase in production and value-added potential, these crops were chosen as the subjects of this experiment.

\subsection{Conclusion}

Since both cocopeat and vermicompost has shown successful results on different plants, they will be assessed simultaneously in this study on boulanger and tomato seedlings. Coco-peat growth medium will be compared to two other growth media (vermicompost and pro-mix) to determine which is the best for boulanger and tomatoseeds germination and also for the production of seedlings of excellent root, shoot and biomass quality. Successful results can supplement or ultimately replace the ever so expensive promix used by farmers in Guyana.

\section{RESEARCH METHODOLOGY}

\subsection{Experimental Set up and Treatments}

This study was carried out in a Seedling Nursery; a shaded facility. This study sought to compare the effects of three growth media on the emergence, growth and development of boulanger and tomato seedlings. Four treatments: (i) cocopeat, (ii) vermicompost, (iii) promix and (iv) a mixture of cocopeat and vermicompost $(\mathrm{c}+\mathrm{v})$ at a 1:1 ratio, were utilised in replicates of three.

Cocopeat was obtained from a local producer in the Pomeroon area, vermicompost was obtained from the Department of Bioenergy's harvest while promix was purchased from a retailer. This experiment was carried out in a completely randomised block design using 24 seedling trays (40 plants per experimental tray). Six trays contained cocopeat, six contained vermicompost, six contained promix and six contained a mixture of cocopeat and vermicompost. Boulanger seeds were sown in three seedling trays containing cocopeat $(\mathrm{C})$, three containing vermicompost $(\mathrm{V})$, three containing promix $(\mathrm{P})$ and three containing a mixture of cocopeat and vermicompost $(\mathrm{C}+\mathrm{V})$. This was done at a depth of approximately half inch in the medium. The same was done for tomato seeds. From the time of sowing to the end of experiment, irrigation rate, temperature and humidity were similar for all treatments. 

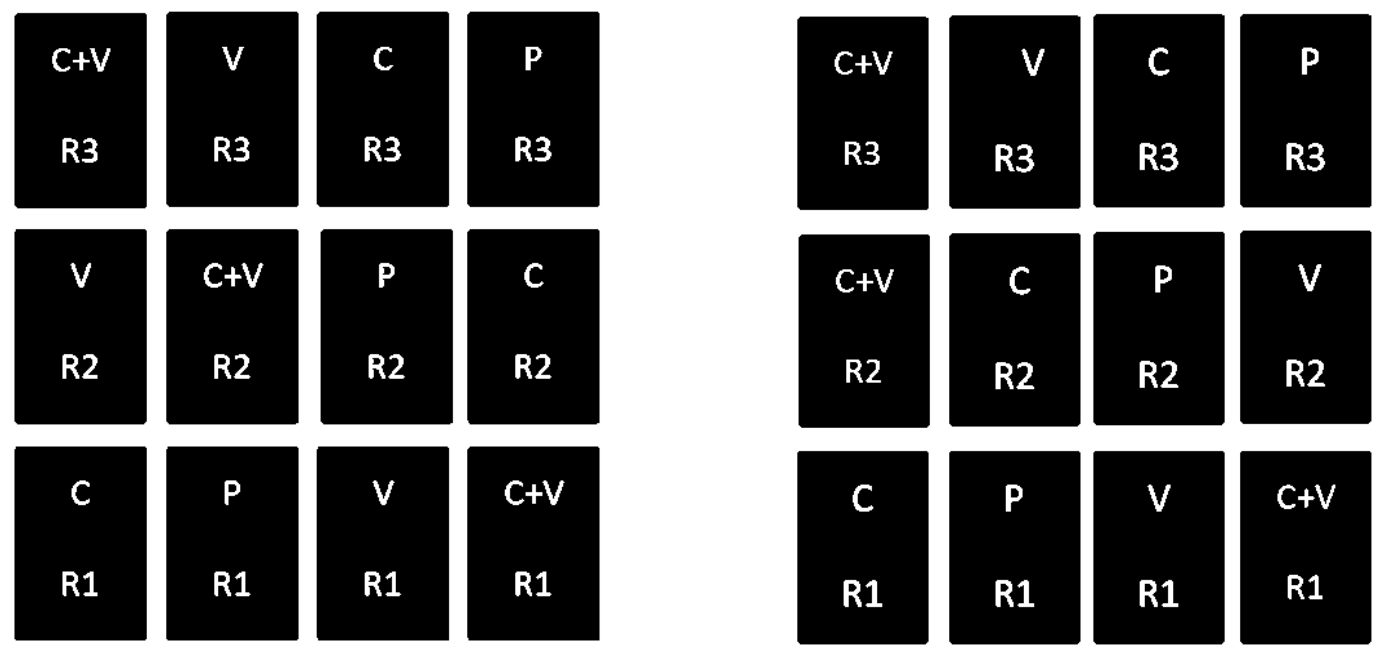

Figure 3.1: Layout of Tomato Treatments; Figure 3.2: Layout of Boulanger Treatments

\subsection{Data Collection}

\subsubsection{Properties of Growth Media}

Prior to the sowing of seeds, physical and chemical analyses of the three growing media were done using various standards outlines in table 3.1. Bulk density was done according to the method followed by Awang et al. (2009). One block of growth media was removed from a container using a ring. The volume of the ring was determined. The soil was oven dried at $105^{\circ} \mathrm{c}$ for 24 hours and then weighed. Bulk density was then calculated using the formula below.

$$
\text { Bulk Density }=\frac{\text { Oven Dried Soil }(g)}{\text { Initial soil Volume }\left(\mathrm{cm}^{2}\right)}
$$

Water holding capacity (WHC) was done by placing a filter paper (fp) inside of a hilgard cup and finding the mass. The cup was filled with oven dried medium and the mass was found. The cup was placed in a shallow pan of water, wetting the bottom two $\mathrm{cm}$. The medium was allowed to become saturated from bottom up. The cup was removed from pan and placed in a humid enclosure until it was completely drained. The mass was recorded. Water holding capacity was then determined using the formulas below.
a. $\quad$ dried soil $(g)=($ cup $+f p+$ dried soil $)(g)-($ cup $+f p)(g)$
b. $\operatorname{saturated} \operatorname{soil}(g)=($ cup $+f p+\operatorname{saturated} \operatorname{soil})(g)-($ Cup $+f p)(g)$
c. water in saturated soil $(g)=\operatorname{saturated}$ soil $(g)-\operatorname{dried} \operatorname{soil}(g)$ 
International Journal of Agriculture and Environmental Research

ISSN: 2455-6939

Volume: 07, Issue: 04 "July-August 2021"

d. $\% W H C=\frac{\text { water in saturated soil }(g)}{\text { saturated soil }(g)} \times 100$

$*_{g}=$ mass in grams

Table 3.1: Parameters and Methods used to analyse the growth medium

\begin{tabular}{|c|c|c|c|}
\hline Symbol & Parameter & Units & Method \\
\hline & Bulk Density & $\mathrm{g} / \mathrm{cm}^{3}$ & Awang et al. (2009) \\
\hline whe & Water Holding Capacity & $\%$ & $\begin{array}{l}\text { ASTM 7263-09 and ASTM } \\
\text { D2980 }\end{array}$ \\
\hline $\mathbf{p H}$ & $\mathrm{pH}$ & & Carter (1993) \\
\hline TOC & $\begin{array}{lll}\text { Total } & \text { Organic } & \text { Carbon } \\
\text { (TOC) } & & \end{array}$ & $\%$ & USEPA 9060 \\
\hline $\mathbf{N}$ & Total Nitrogen & $\mathrm{mg} / \mathrm{kg}$ & ASTM D7582 \\
\hline $\mathbf{C a}$ & Calcium & $\mathrm{mg} / \mathrm{kg}$ & \multirow{8}{*}{$\begin{array}{l}\text { US EPA } 3050 \text { B and SMEWW } \\
3120 \text { B }\end{array}$} \\
\hline Mg & Magnesium & $\mathrm{mg} / \mathrm{kg}$ & \\
\hline $\mathbf{K}$ & Potassium & $\mathrm{mg} / \mathrm{kg}$ & \\
\hline $\mathbf{P}$ & Phosphorous & $\mathrm{mg} / \mathrm{kg}$ & \\
\hline $\mathbf{C u}$ & Copper & $\mathrm{mg} / \mathrm{kg}$ & \\
\hline Mn & Manganese & $\mathrm{mg} / \mathrm{kg}$ & \\
\hline $\mathbf{F e}$ & Iron & $\mathrm{mg} / \mathrm{kg}$ & \\
\hline $\mathbf{Z n}$ & Zinc & $\mathrm{mg} / \mathrm{kg}$ & \\
\hline
\end{tabular}

*ASTM-American Society for Testing in Materials

*USEPA- United States Environmental Protection Agency

*SMEWW-Standard Methods for the Examination of Water and Waste Water 
International Journal of Agriculture and Environmental Research

ISSN: 2455-6939

Volume: 07, Issue: 04 "July-August 2021"

\subsubsection{Seedling Growth}

The effects of the different growth media were evaluated on the seedlings by collecting data on length of shoot, number of leaves, leaf length, leaf width, root length and fresh weight of seedlings at the end of eight weeks. Shoot length was measured from the medium line to the top of the seedling while root length was measured after shaking off the medium. Number of leaves were counted manually while the leaf length and width were measured using a ruler. Fresh weight of seedlings were taken by cleaning the medium off the roots and then weighed on a digital balance. Dry weight of roots and shoots was done by separating the root from shoot and drying at $80^{\circ} \mathrm{C}$ for 72 hours (Awang et al., 2009).

\subsection{Data Analysis}

Microsoft Excel was used to tabulate and graphically display the findings while Statistix 10 was used to conduct the analysis of variance (ANOVA) test to determine if there are significant differences among the growth parameters of the seedlings grown in the three media. Least significant differences (LSD) pairwise test was used to compare the means of the treatments.

\section{RESULTS AND DISCUSSION}

\subsection{Growth media properties}

The four growth media treatments used for this study were cocopeat, vermicompost, promix and a mixture of vermicompost and cocopeat at a 1:1 ratio. Results of the physical and chemical analyses of each growth media is presented in Table 4.1. Analyses reveal that cocopeat and promix has the best physical structure; lower bulk density and higher water holding capacity than vermicompost. Riaz et al., (2008) indicated that water holding capacity is one of the most important physical characteristics of growth medium. Kukal et al., (2012) indicated that lower bulk density of growth media containing higher ratios of cocopeat is due to its light weight and its increased pore spaces.

The $\mathrm{pH}$ of cocopeat used in this study (5.05) is comparable to the $\mathrm{pH}$ of the cocopeat (5.08) analysed by Bullaram et al. (2016) while the $\mathrm{pH}$ of the vermicompost is comparable to Abrahim et al. (2016). Since promix is a commercially prepared medium, its $\mathrm{pH}$ would have been altered to an ideal value of 6.2. Even though different plants require different $\mathrm{pH}$ levels, Bullaram et al. (2016) recommended that a $\mathrm{pH}$ of between 5.2 and 6.3 as ideal for growth medium which indicates that each of the growth medium used are ultimate as it relates to $\mathrm{pH}$.

Nutrient status also influences plant development. The most important chemical factors necessary for plant development include the nutrient content (Riaz et al., 2008). Cocopeat 
contains the highest $\mathrm{N}, \mathrm{Ca}, \mathrm{P}, \mathrm{Zn}$ and TOC content, all comparable to the analyses done by Shanmugasundaram et al. (2013) and contrary to Wilkinson et al. (2014). Vermicompost contains the highest concentrations of $\mathrm{Mg}, \mathrm{K}$ and $\mathrm{Fe}$ with all analyses comparable to the findings of Abrahim et al. (2016) and Yadav et al. (2013). Promix contains the highest concentrations of $\mathrm{Cu}$ and $\mathrm{Mn}$ and the lowest concentrations of $\mathrm{N}, \mathrm{Ca}, \mathrm{mg}, \mathrm{P}$ and $\mathrm{Zn}$.

Table 4.1: Results of Physio-Chemical Analyses of the Growth Media

\begin{tabular}{|l|l|l|l|}
\hline Parameter & Cocopeat & Vermicompost & Promix \\
\hline Bulk Density (g/cm $\left.{ }^{\mathbf{3}}\right)$ & 0.06 & 0.34 & 0.03 \\
\hline WHC (\%) & 71 & 43.80 & 77 \\
\hline pH & 5.05 & 5.29 & 6.2 \\
\hline TOC (\%) & 91.7 & 5.18 & 6.35 \\
\hline Total N (mg/kg) & 10,050 & 9100 & 6500 \\
\hline Ca (mg/kg) & 1.78 & 1.66 & 0.48 \\
\hline Mg (mg/kg) & 5.93 & 10.55 & 2.78 \\
\hline K (mg/kg) & 5.17 & 7.61 & 5.41 \\
\hline P (mg/kg) & 200 & 102 & 80 \\
\hline Cu (mg/kg) & 0.35 & 0.22 & 0.57 \\
\hline Mn (mg/kg) & 23.4 & 40.6 & 54.2 \\
\hline Fe (mg/kg) & 0.51 & 5.11 & 29.7 \\
\hline Zn (mg/kg) & 77 & 28.8 & \\
\hline
\end{tabular}

\subsection{Vegetative growth characteristics}

Six vegetative growth parameters of boulanger seedlings and five of tomato seedlings were evaluated to determine the effects of the different media on plant development. These parameters include shoot length, number of leaves, leaf length, leaf width, root length and fresh weight of seedlings. The findings are presented in tables 4.2 and 4.3. The growth medium of any plant is 
International Journal of Agriculture and Environmental Research

ISSN: 2455-6939

Volume: 07, Issue: 04 "July-August 2021"

known to influence the quality of the plant (Bhardwaj, 2014). Each parameter influenced is discussed below.

Table 4.2: Effects of the different growth media on vegetative growth of boulanger seedlings

\begin{tabular}{|l|l|l|l|l|l|c|}
\hline Treatment & $\begin{array}{l}\text { Length } \\
\text { of shoot }\end{array}$ & $\begin{array}{l}\text { Number } \\
\text { of leaves }\end{array}$ & $\begin{array}{l}\text { Avg. leaf } \\
\text { length }\end{array}$ & $\begin{array}{l}\text { Avg. leaf } \\
\text { width }\end{array}$ & $\begin{array}{l}\text { Root } \\
\text { length }\end{array}$ & $\begin{array}{l}\text { Fresh wt. } \\
\text { of seedling }\end{array}$ \\
\hline Cocopeat & $5.81^{\mathrm{b}}$ & $3.24^{\mathrm{a}}$ & $1.88^{\mathrm{b}}$ & $1.65^{\mathrm{b}}$ & $10.70^{\mathrm{b}}$ & $0.56^{\mathrm{b}}$ \\
\hline Vermicompost & $7.56^{\mathrm{a}}$ & $3.81^{\mathrm{a}}$ & $2.76^{\mathrm{a}}$ & $2.44^{\mathrm{a}}$ & $10.85^{\mathrm{b}}$ & $1.01^{\mathrm{a}}$ \\
\hline Promix & $4.70^{\mathrm{c}}$ & $2.64^{\mathrm{b}}$ & $1.51^{\mathrm{c}}$ & $1.15^{\mathrm{c}}$ & $7.47^{\mathrm{c}}$ & $0.26^{\mathrm{c}}$ \\
\hline $\begin{array}{l}\text { Vermicompost } \\
+ \text { Cocopeat }\end{array}$ & $7.39^{\mathrm{a}}$ & $3.85^{\mathrm{a}}$ & $2.67^{\mathrm{a}}$ & $2.07^{\mathrm{a}}$ & $16.92^{\mathrm{a}}$ & $1.08^{\mathrm{a}}$ \\
\hline Anova $\alpha 0.05$ & $7.88^{-73}$ & $6.65^{-16}$ & $8.12^{-54}$ & $1.17^{-08}$ & $1.59^{-31}$ & $6.50^{-71}$ \\
\hline
\end{tabular}

*Values in each column with same letter did not differ significantly according to LSD at $\mathrm{p}<0.05$

$¥$ - indicates the significant differences amongst the treatment

Table 4.3: Effects of the different growth media on vegetative growth of tomato seedlings

\begin{tabular}{|l|c|c|c|c|c|}
\hline Treatment & $\begin{array}{l}\text { Length of } \\
\text { shoot }\end{array}$ & $\begin{array}{l}\text { Number of } \\
\text { leaves }\end{array}$ & $\begin{array}{l}\text { Avg. leaf } \\
\text { length }\end{array}$ & $\begin{array}{l}\text { Root } \\
\text { length }\end{array}$ & $\begin{array}{l}\text { Fresh wt. of } \\
\text { seedling }\end{array}$ \\
\hline Cocopeat & $7.41^{\mathrm{b}}$ & $3.78^{\mathrm{c}}$ & $2.87^{\mathrm{b}}$ & $12.61^{\mathrm{c}}$ & $0.55^{\mathrm{b}}$ \\
\hline Vermicompost & $9.88^{\mathrm{a}}$ & $4.58^{\mathrm{a}}$ & $4.35^{\mathrm{a}}$ & $14.90^{\mathrm{b}}$ & $1.16^{\mathrm{a}}$ \\
\hline Promix & $6.872^{\mathrm{c}}$ & $3.18^{\mathrm{d}}$ & $2.68^{\mathrm{b}}$ & $12.49^{\mathrm{c}}$ & $0.45^{\mathrm{b}}$ \\
\hline $\begin{array}{l}\text { Vermicompost } \\
\text { and Cocopeat }\end{array}$ & $10.10^{\mathrm{a}}$ & $4.20^{\mathrm{b}}$ & $4.37^{\mathrm{a}}$ & $16.47^{\mathrm{a}}$ & $1.15^{\mathrm{a}}$ \\
\hline Anova $\boldsymbol{\alpha 0 . 0 5}$ & $4.66^{-48}$ & $3.66^{-18}$ & $4.04^{-37}$ & $9.80^{-7}$ & $6.15^{-47}$ \\
\hline
\end{tabular}

*Values in each column with same letter did not differ significantly according to LSD at $\mathrm{p}<0.05$

$¥$ - indicates the significant differences amongst the treatments 
International Journal of Agriculture and Environmental Research

ISSN: 2455-6939

Volume: 07, Issue: 04 "July-August 2021"

\subsubsection{Shoot Length}

The media used for tomato and boulanger seedling production significantly influenced the differences in shoot lengths of the plants $(\mathrm{p}<0.05)$. In tables 4.2 and 4.3 , it is evident that both plant types produced in vermicompost and the mixture of vermicompost and cocopeat possessed significantly taller shoots than those produced in cocopeat and promix. Vermicompost produced the tallest boulanger seedlings $(7.56 \mathrm{~cm})$ that were $2.25 \%$ taller than those in the mixture whose seedlings were $21.38 \%$ taller than those in cocopeat. Seedlings grown in cocopeat were $19.11 \%$ taller than those grown in promix. Tomato seedlings on the other hand were the tallest $(10.10 \mathrm{~cm})$ when grown in the mixture. These seedlings were $2.67 \%$ taller than those in vermicompost while those in vermicompost were $25 \%$ taller than those in cocopeat. Cocopeat seedlings were $7.26 \%$ taller than those in promix.

LSD pair wise statistical test indicates that the mean length of shoots of the seedlings produced in vermicompost and the mixture of vermicompost and cocopeat are not significantly different. The tall shoots of seedlings grown in vermicompost, vermicompost and cocopeat mixture and cocopeat only can be attributed to the high nitrogen and calcium content of the two media (table 1). Treder (2008) found that high $\mathrm{N}$ and $\mathrm{Ca}$ content of growth media produced plants with taller stems. This finding also supports Zaller (2007) who found that vermicompost influenced the elongation of seedlings when used for tomato seedling production. Promix produced the shortest seedlings and this can be attributed to its low $\mathrm{N}$ and $\mathrm{Ca}$ content as compared to cocopeat and vermicompost (Treder, 2008). Contradicting findings were reported by Mathowa et al. (2016) who found thata similar commercial media (hydromix) produced taller seedlings than the cocopeat medium.

\subsubsection{Number of leaves per plant}

The number of leaves per plant was significantly affected by their respective growth medium $(\mathrm{p}<0.05)$. Boulanger seedlings grown in vermicompost and cocopeat mixture produced the most leaves (3.85), 1.04\% more than those in grown on vermicompost, whose seedlings bore $14.96 \%$ more leaves than those grown in cocopeat. Boulanger seedlings grown in cocopeat only bore $18.52 \%$ more leaves than those grown in promix. Tomato seedlings grown in vermicompost bore the most leaves (4.58), which was $25 \%$ more than those grown in the mixture of vermicompost and cocopeat. The mixture produced tomato plants with $10 \%$ more leaves than cocopeat while the cocopeat tomato seedlings produced $16 \%$ more leaves than promix.

LSD pairwise test found that the mean number of leaves of the boulanger seedlings grown in cocopeat, vermicompost and the mixture are not significantly different. On the contrary, the means of the tomato seedlings grown in the four media were significantly different. This 
International Journal of Agriculture and Environmental Research

ISSN: 2455-6939

Volume: 07, Issue: 04 "July-August 2021"

supports Abrahim et al. (2016) who found lettuce and cabbage grown in vermicompost amended soils to have more leaves than the other treatments. These results also support the conclusions of Eudoxie and Alexander (2011) who found that promix produced tomato seedlings that were significantly shorter than those produced in other organic media.

\subsubsection{Average leaf length and width}

The leaf size of boulanger and tomato seedlings grown in the four different medium were significantly different $(\mathrm{p}<0.05)$. The largest leaves of the boulanger seedlings $(2.76 \mathrm{~cm}$ in length and $2.44 \mathrm{~cm}$ in width) were produced in the vermicompost medium. These were longer and wider than those grown in the mixture by $3.27 \%$ and $15 \%$ respectively. The mixture produced seedlings with leaves that were $28 \%$ longer and $20 \%$ wider than those grown in cocopeat while cocopeat produced seedlings with leaves that were $20 \%$ longer and $30 \%$ wider than those grown in promix. Tomato seedlings on the other hand produced the longest leaves when grown in the mixture of vermicompost and cocopeat $(4.37 \mathrm{~cm})$ which was $0.50 \%$ longer than those grown in vermicompost. Vermicompost produced tomato seedlings with leaves that were 34\% longer than those in cocopeat, whose leaves were $6.62 \%$ longer than promix's seedlings.

LSD pairwise test confirmed that there were no significant differences in the means of the leaf sizes of seedlings produced in vermicompost and the mixture of vermicompost and cocopeat for both plant types. The mean leaf sizes of seedlings grown in cocopeat and promix were similar for tomato seedlings but different for boulanger seedlings. Similar results were reported by Arancon et al., (2005), who found that leaf size of pepper plants were enhanced when grown in vermicompost medium.

\subsubsection{Root length}

Root lengths of boulanger and tomato seedlings produced in the different growth media were significantly different $(\mathrm{p}<0.05)$. The boulanger seedlings grown in the mixture of vermicompost and cocopeat possessed the longest roots $(16.92 \mathrm{~cm})$ which was longer $(35.87 \%)$ than those grown in vermicompost. Boulanger seedlings grown in vermicompost possessed $1.4 \%$ longer roots than those grown in cocopeat which produced seedlings that were $30 \%$ longer than promix's seedlings. The tomato seedlings of longest roots $(16.47 \mathrm{~cm})$ were also produced in the mixture and these were $10 \%$ longer than those produced in vermicompost. Tomato seedlings grown in vermicompost were $15.4 \%$ longer than those grown in cocopeat while cocopeat's seedlings were $0.50 \%$ longer than promix's seedlings.

LSD pairwise test shows that vermicompost only and cocopeat only produced boulanger seedlings of similar root lengths while tomato seedlings produced in these two media were different. Promix produced boulanger seedlings with roots that were significantly shorter than 
International Journal of Agriculture and Environmental Research

ISSN: 2455-6939

Volume: 07, Issue: 04 "July-August 2021"

those in grown in cocopeat but tomato seedlings grown in these two medium were of similar root lengths. Results show that the mixture of vermicompost and cocopeat produced boulanger and tomato seedlings of longer roots than vermicompost or cocopeat used individually. This positive effect can be attributed to the excellent physical (table 4.1) and biological properties of the cocopeat which adds value to the nutrient-high vermicompost while providing a porous environment that aids healthy root development. These results support Treder (2008) who found root lengths of lilies grown in cocopeat amended medium to be significantly higher than the other treatments.

As it relates to root length, the best root qualities of for both plant types were of those seedlings grown in the mixture of vermicompost and cocopeat. This is due to the high $\mathrm{P}$ content of cocopeat, which is known to aid root development, supporting the already nutrient rich and fast releasing vermicompost. Together with high level of $\mathrm{P}$, cocopeat provides an excellent rooting environment for the seedlings with its high water-holding capacity, excellent drainage, excellent physical resiliency, slow decomposition and easy wettability as reported by Wilkinson et al. (2014).

\subsubsection{Fresh weight of Seedlings}

The fresh weight of seedlings grown in the four different medium were significantly different $(\mathrm{p}<0.05)$. Boulanger seedlings grown in cocopeat and vermicompost mixture had the highest weights; $6.00 \%$ more than those grown in vermicompost only. Those produced in vermicompost had $44.56 \%$ more weight than those grown in cocopeat. Boulanger seedlings produced in cocopeat were of $53.58 \%$ more weight than those grown in promix. Tomato seedlings on the other hand had a higher weight $(0.86 \%)$ when grown in vermicompost than those grown in the mixture of vermicompost and cocopeat. Vermicompost produced tomato seedlings that weighed $52.18 \%$ more than those produced in cocopeat while cocopeat produced seedlings that were $18.19 \%$ heavier than those grown in promix. For both types of seedlings, those grown in cocopeat were of the third highest weight while those in promix were of the lowest weights.

LSD pairwise test shows that the weights of both types of seedlings grown in vermicompost only and the mixture of vermicompost and cocopeat were not significantly different. Boulanger seedlings grown in promix were significantly lighter than those in cocopeat but similar for tomato. These results support Awang et al. (2009) who found that Celosia cristata grown in cocopeat only weighedless than those grown in other medium. These results also support Abrahim et al., (2016) who found that pakchoi, lettuce and cabbage produced in vermicompostwere of excellent quality (weight), comparable to those fertilized with synthetic fertilizers. 
International Journal of Agriculture and Environmental Research

ISSN: 2455-6939

Volume: 07, Issue: 04 "July-August 2021"

Despite the fact cocopeat was the richest in $\mathrm{N}$, it did not produce plants with the best shoot qualities since it is known to immobilize nitrogen, hence plants are not able to utilise $\mathrm{N}$ efficiently (Bullaram et al., 2016). It can be deduced that even though cocopeat has excellent physical characteristics and has a high nutrient content, it is known to release these nutrients very slowly as reported by Sriram et al. (2010). The time taken for it to release nutrients may not be within the time frame necessary to produce tomato and Boulanger seedlings of the best qualities for transplanting. As such, it did not produce the best seedlings.

Vermicompost and the mixture of vermicompost and cocopeat competed interchangeable and closely as it pertains to all growth parameters of both tomato and boulanger seedlings. These two media produced seedlings of good qualities. The mixture however is an ideal growth medium as it topped in four of the six growth parameters of boulanger seedlings and three of the five growth parameters of the tomato seedlings. This excellent performance can be attributed to vermicompost's ability to quickly release nutrients to the seedlings and the ideal physical environment provided by cocopeat. These excellent physical conditions provided by cocopeat include moisture retention and oxygen availability for seedling development as reported by Wilkinson et al. (2014). Promix on the other hand boasted excellent physical structure but it was poor in essential nutrients (N., P, K and Ca) needed for enhanced plant growth, hence it produced seedlings that were of the poorest qualities.

\section{CONCLUSION}

Using soilless growth media for seedling production is a fairly new undertaking by nurseries in Guyana. This experiment was conducted to firstly determine the differences among the physical and chemical properties of four growth medium materials namely vermicompost, cocopeat, promix and a mixture of vermicompost of cocopeat at a 1:1 ratio. Secondly, this study also sought to determine the effects the four growth medium on biomass, shoot and root development of boulanger and tomato seedlings.

Results indicate that the physical and chemical properties of the three growth media materials were significantly different with cocopeat and promix having the higher bulk density and water holding capacity. It can be deduced that the medium containing 50\% cocopeat and 50\% vermicompost showed overall desirable results in tomato and Boulanger seedling production. The results indicate that the mixture had significant positive effect on four growth parameters of boulanger (number of leaves, leaf width, root length and fresh weight) and three growth parameters of tomato seedlings (shoot length, leaf length and root length). Even though vermicompost and cocopeat were of high nutrient content individually, the treatment containing $50 \%$ vermicompost and 50\% cocopeat outperformed the treatments containing $100 \%$ cocopeat, 
International Journal of Agriculture and Environmental Research

ISSN: 2455-6939

Volume: 07, Issue: 04 "July-August 2021"

$100 \%$ vermicompost and $100 \%$ promix as it relates to growth characteristics. As such it can be concluded that the mixture is an ideal medium for boulanger and tomato seedling production.

\section{REFERENCES}

[1] Abad, M., Noguera, P., Puchades, R., Maguiera, A. and Noguera, V. 2002. Physiochemical and chemical properties of some coconut dusts for use as peat substitute for containerized ornamental plants. Bioresearch Technology [Online]. 82, 241-245. $\begin{array}{llllll}\text { [Accessed } & 19 & \text { February 2018]. } & \text { Available }\end{array}$ https://www.ncbi.nlm.nih.gov/pubmed/11991072

[2] Bullaram, U., Chooneea, M. and Ellapen, A. 2016. A Study on the Physico-Chemical Suitability of Locally Available Coconut Coir for Soilless Crop Production in Mauritius.University of Mauritius Research Journal [Online]. 22(A), 29-44. [Accessed 06 September 2018]. Available from http://vcampus.uom.ac.mu/pvcacd/uploads/uomjournals/41/RJ284FinalPaperacceptedon3 0August2016.pdf

[3] Abrahim, B. N., Clementson, C., Homenauth, O. and Persaud, V. 2016. An Evaluation of 'Vinasse' (Bio-Ethanol Effluent) and Vermicompost as Soil Amendments for Cash Crop Production.Greener Journal of Agricultural Sciences. [Online]. 6 (9), 256-261. [Accessed 19 February 2018]. Available from http://gjournals.org/GJAS/Publication/2016/October/HTML/092816148\%20Clairmont\% 20et\%20al.htm

[4] Arancon, N.Q., Edwards, C, A., Bier, P., Metzger, J.D. and Lucht, C. (2005). Effects of vermicomposts produced from cattle manure, food waste and paper waste on the growth and yield of peppers in the field. Pedobiologia [Online]. 49( 4), 297-306. [Accessed 21 February, 2018]. Available from https://www.sciencedirect.com/science/article/abs/pii/S003140560500017X

[5] Atiyeh, R.M., Dominguez, J., Subler, S. and Edwards, C.A. 2000. Changes in biochemical properties of cow manure during processing by earthworms (Eiseniaandrei, Bouché) and the effects on seedling growth. Pedobiologia [Online]. 44 (6), 709-724. [Accessed $20 \quad$ February, 2018]. Available from https://www.sciencedirect.com/science/article/abs/pii/S0031405604700840

[6] Awang, Y., Shaharom, A.S., Mohamad, R.B. and Selamat, A.2009. Chemical and Physical Characteristics of Cocopeat-Based Media Mixtures and Their Effects on the Growth and Development of Celosia cristata. American Journal of Agricultural and Biological Sciences. [Online]. 4 (1), 63-71. [Accessed 19 February, 2018]. Available from https://pdfs.semanticscholar.org/d6ef/4c3c8d7cd7d812389957ddc3b2629b45e3fd.pdf 
International Journal of Agriculture and Environmental Research

ISSN: 2455-6939

Volume: 07, Issue: 04 "July-August 2021"

[7] Bhardwaj, R.L. 2014. Effect of growing media on seed germination and seedling growth of papaya c.'Red lady'. African Journal of Plant Science [Online]. 8(4), 178-184. [Accessed 19 February, 2018]. Available from http://www.academicjournals.org/journal/AJPS/article-abstract/FA9447944194

[8] Eudoxie, G.D. and Alexander, I.A. (2011). Spent Mushroom Substrate as a Transplant Media Replacement for Commercial Peat in Tomato Seedling Production. Journal of Agricultural Science [Online]. 3(4). [Accessed 26 February, 2018]. Available from http://www.ccsenet.org/journal/index.php/jas/article/view/8993/9111

[9] Khayyat, M., F. Nazari and H. Salehi. 2007. Effects of Different Pot Mixtures on Pothos (EpipremnumaureumLindl. and Andre 'GoldenPothos') Growth and Development. American-Eurasian Journal of Agriculture and Environmental Sciences [Online]. 2: 341348. [Accessed 26 February, 2018]. Available from https://www.researchgate.net/publication/211547556_Effects_of_Different_Pot_Mixtures _on_Pothos_Epipremnum_aureum_Lindl_and_Andre_Golden_Pothos'_Growth_and_De velopment

[10] Kukal, S.S., Saha, D., Bhowmik, A. and Dubey, R.K. 2012. Water retention characteristics of soil bio-amendments used as growing media in pot culture. Journal of Applied Horticulture [Online]. 14(2). [Accessed 26 February 2018]. Available from https://www.researchgate.net/profile/Surinder_Kukal/publication/265382743_Water_rete ntion_characteristics_of_soil_bio-

amendments_used_as_growing_media_in_pot_culture/links/558148ad08aed40dd8cd4d4

4/Water-retention-characteristics-of-soil-bio-amendments-used-as-growing-media-in-potculture.pdf.

[11] Mastalerz, J.W. 1977. The greenhouse environment. New York: John Wiley \& Sons. 629 $\mathrm{p}$

[12] Mathowa, T., Tshegofatso, N., Mojeremane, W., Matsuane, C., Legwaila, G.M. and Oagile, O. 2016. Effect of commercial growing media on emergence, growth and development of tomato seedlings.International Journal Agriculture Research [Online]. 9(1), 83-91. [Accessed 26 February, 2018]. Available from http://www.innspub.net/ijaar/effect-of-commercial-growing-media-on-emergencegrowth-and-development-of-tomato-seedlings/

[13] Ministry of Agriculture (2007). Farmer's Manual.

[14] National Agricultural Research Institute, Ministry of Fisheries, Crops and Livestock and New Guyana Marketing CorPoration. 2003. Tomato Post Harvest Care and Market Preparation. Postharvest Handling Technical Bulletin [Online]. Bulletin No. 9. [Accessed 04 May, 2018]. Available from http://agriculture.gov.gy/wpcontent/uploads/2016/01/Tomato.pdf 
International Journal of Agriculture and Environmental Research

ISSN: 2455-6939

Volume: 07, Issue: 04 "July-August 2021"

[15] National Agricultural Research and Extension Institute. 2017. The Coconut Industry in Guyana. [Online]. [Accessed 19 February, 2018]. Available from http://narei.org.gy/thecoconut-industry-in-guyana/

[16] National Agricultural Research and Extension Institute. undated. Growing Tomatoes in Guyana. [Online]. [Accessed 14 May, 2018]. Available from https://www.ecofog.gf/giec/doc_num.php?explnum_id=1010

[17] Riaz, A., Arshad, M., Younis, A., Raza, A. and Hameed, M. 2008. Effects of different growing media on growth and flowering of Zinnia Elegans cv. Blue point. Pakistan Journal of Botany [Online]. 40(4), 1579-1585. [Accessed 22 February, 2018]. Available from http://www.pakbs.org/pjbot/PDFs/40(4)/PJB40(4)1579.pdf

[18] Sereme, A., Dabire, C., Koala, M., Somda, M.K. and Traore, A.S., 2016. Influence of organic and mineral fertilizers on the antioxidants and total phenolic compounds level in tomato (Solanumlycopersicum) var. Mongal F1. Journal of Experimental Biology and Agricultural Sciences [Online], 4(4), pp.414-420. [Accessed 14 May, 2018]. Available from http://jebas.org/Jou.Exp.Bio.Agr.Sci/00400425062016/10.18006_2016.4(4).414.420.pdf

[19] Sindhu, S.S., D.B. Gholap., M.C. Singh and M.R. Dhiman. 2010. Effect of medium amendments on growth and flowering in gerbera. Indian Journal of Horticulture [Online]. 67(Special Issue), 391-394. [Accessed February 20, 2018]. Available from https://www.researchgate.net/profile/Mam_Singh/publication/288569651_Effect_of_med ium_amendments_on_growth_and_flowering_in_gerbera/links/5862251708ae6eb871a9e a4b/Effect-of-medium-amendments-on-growth-and-flowering-in-gerbera.pdf

[20] Singh, R,B. 2000. Environmental consequences of agricultural development: a case study from the Green Revolution state of Haryana, India [Online]. 82(1-3), 97-103. [Accessed 19 February 2018]. Available from https://www.sciencedirect.com/science/article/pii/S016788090000219X

[21] Sriram, S., Savitha, M.J. and Ramanujam,B. 2010. Trichoderma-enriched coco-peat for the management of Phytophthora and Fusariumdiseases of chilli and tomato in nurseries.Journal of Biological Control [Online].24(4), 311-316. [Accessed 26 February, 2018].

Available

from https://www.researchgate.net/profile/Subbaraman_Sriram2/publication/236229298_Trich oderma-enriched_coco-

peat_for_the_management_of_Phytophthora_and_Fusarium_diseases_of_chilli_and_tom ato_in_nurseries/links/0c9605172456238d69000000/Trichoderma-enriched-coco-peatfor-the-management-of-Phytophthora-and-Fusarium-diseases-of-chilli-and-tomato-innurseries.pdf 
[22] Tilman, D. 1998. The Greening of the Green Revolution. Nature. [Online]. 396, 211-212. [Accessed 19 February, 2018]. Available from https://www.nature.com/articles/24254.

[23] Treder, J. 2008. The effects of cocopeat and ferltilization on the growth and flowering of oriental lily 'Star Gazer.' Journal of Fruit and Ornamental Plant Research. [Online]. 16, 361-370. [Accessed August 28 2018]. Available from https://www.scribd.com/document/255751745/THE-EFFECTS-OF-COCOPEAT-ANDFERTILIZATION-ON-THE-GROWTH-AND-FLOWERING-OF-ORIENTAL-LILYSTAR-GAZER

[24] Wilkinson, Kim M.; Landis, Thomas D.; Haase, Diane L.; Daley, Brian F.; Dumroese, R. Kasten, eds. 2014. Tropical Nursery Manual: A guide to starting and operating a nursery for native and traditional plants. Agriculture Handbook 732. Washington, DC: U.S. Department of Agriculture, Forest Service [Online]. 100- 121. [Accessed February 19, 2018]. Available from https://www.fs.usda.gov/treesearch/pubs/46345

[25] Yadav, A., Gupta, A. and Garg, V.K. 2013.Organic manure production from cow dung and biogas plant slurry by vermicomposting under field conditions. International Journal Of Recycling of Organic Waste in Agriculture [Online]. 2(21).[Accessed 21 February, 2018]. Available from https://link.springer.com/article/10.1186/2251-7715-2-21

[26] Zaller, J.G. 2007. Vermicompost as a substitute for peat in potting media: Effects on germination, biomass allocation, yields and fruit quality of three tomato varieties. Scientia Horticulturae [Online]. 112, (2), 191-199. [Accessed February 20 2018]. Available from https://www.sciencedirect.com/science/article/pii/S0304423806005103 